\title{
Genetic characterization of Theileria equi infecting horses in North America: evidence for a limited source of U.S. introductions
}

\author{
Carina M Hall1', Joseph D Busch', Glen A Scoles², Kristina A Palma-Cagle', Massaro W Ueti ${ }^{2}$ \\ Lowell S Kappmeyer ${ }^{2}$ and David M Wagner ${ }^{1 *}$
}

\begin{abstract}
Background: Theileria equi is a tick-borne apicomplexan hemoparasite that causes equine piroplasmosis. This parasite has a worldwide distribution but the United States was considered to be free of this disease until recently.

Methods: We used samples from 37 horses to determine genetic relationships among North American T. equi using the $18 \mathrm{~S}$ rRNA gene and microsatellites. We developed a DNA fingerprinting panel of 18 microsatellite markers using the first complete genome sequence of T. equi.

Results: A maximum parsimony analysis of 185 rRNA sequences grouped the samples into two major clades. The first clade $(n=36)$ revealed a high degree of nucleotide similarity in U.S. T. equi, with just 0-2 single nucleotide polymorphisms (SNPs) among samples. The remaining sample fell into a second clade that was genetically divergent (48 SNPs) from the other U.S. samples. This sample was collected at the Texas border, but may have originated in Mexico. We genotyped T. equi from the U.S. using microsatellite markers and found a moderate amount of genetic diversity (2-8 alleles per locus). The field samples were mostly from a 2009 Texas outbreak $(n=22)$ although samples from five other states were also included in this study. Using Weir and Cockerham's $F_{\text {ST }}$ estimator $(\theta)$ we found strong population differentiation of the Texas and Georgia subpopulations $(\theta=0.414)$, which was supported by a neighbor-joining tree created with predominant single haplotypes. Single-clone infections were found in 27 of the 37 samples (73\%), allowing us to identify 15 unique genotypes.
\end{abstract}

Conclusions: The placement of most T. equi into one monophyletic clade by $18 \mathrm{~S}$ is suggestive of a limited source of introduction into the U.S. When applied to a broader cross section of worldwide samples, these molecular tools should improve source tracking of T. equi outbreaks and may help prevent the spread of this tick-borne parasite.

Keywords: Babesia equi, Theileria equi, Equine piroplasmosis, 185 rRNA gene, Microsatellite, Population genetics

\section{Background}

The apicomplexan protozoan Theileria equi (also known as Babesia equi) causes equine piroplasmosis (EP) and is a growing threat to the horse industry [1-3]. T. equi is an obligate intracellular parasite that requires a tick host for sexual reproduction and an equine host for asexual reproduction during a haploid phase [2]. T. equi can be naturally transmitted by ticks of the family Ixodidae [4] and, in addition to this biological route, T. equi has the

\footnotetext{
* Correspondence: dave.wagner@nau.edu

${ }^{1}$ Center for Microbial Genetics and Genomics, Northern Arizona University, 1298 S Knoles Drive, Flagstaff, AZ 86011, USA

Full list of author information is available at the end of the article
}

potential to be transmitted iatrogenically [5]. In fact, iatrogenic transmission is thought to have been the primary mode of transmission in an outbreak in Florida, U.S., in 2008 [6]. Once a horse becomes infected, the parasite undergoes asexual reproduction within erythrocytes; high parasitemia is found during this acute phase of infection [7]. If the horse overcomes the acute infection it will typically carry a life-long persistent infection that is usually asymptomatic [8]. Due to the low parasitemia that is characteristic of a persistent infection the parasite is not detectable by microscopic examination of blood smears. However, infections can be detected by serology and PCR. Although asymptomatic horses have

\section{Biomed Central}


low parasitemia, transmission of T. equi can still occur either iatrogenically, or when competent tick vectors feed on these horses [2,9]. Thus, asymptomatic persistently infected carriers can serve as reservoirs of infection, which is one of the challenges for controlling the spread of this parasite.

When naïve horses are parasitized by $T$. equi the infection can cause a range of disease symptoms up to and including death. Although this parasite is less prevalent in countries such as the U.S., Australia, England and Canada, even with transport regulations there is a potential for spread from infected horses or ticks from endemic regions [10]. The U.S. was thought to be free of EP since 1988 as the result of a twelve million dollar, 25 year-long eradication campaign that began in 1962 [6]. However, since 2008 numerous cases of T. equi infection have been identified in the U.S. in California, Colorado, Florida, Georgia, Oklahoma and Texas. These are most likely the outcome of importing asymptomatic horses that produced negative results during mandatory screening procedures $[6,11,12]$. A large outbreak in Texas caused alarm when positive horses from 16 states were epidemiologically traced back to a single source ranch $[11,12]$. With over 9.2 million horses in the U.S., a widespread outbreak could have a large financial impact on the $\$ 39$ billion horse industry [13]. Due to concerns about importing T. equi into nonendemic regions, the World Organization for Animal Health (OIE) and U.S. Department of Agriculture (USDA) implemented a mandatory screening process for international movement of horses. When horses are imported into the U.S. they are screened with a serological assay to ensure they are free of T. equi. Prior to 2005 the complement fixation test (CFT) was used as the regulatory test of choice, but since that time import testing has included a competitive enzyme-linked immunosorbent assay (cELISA) [14]. DNA-based methods have also been developed for screening horses and these may be more sensitive for detecting early infection, or very lowlevel parasitemia [15].

Molecular genetic tools provide a powerful means for detecting and tracking the spread of cryptic pathogens and parasites such as Plasmodium falciparum and P. vivax [16-19]. Although molecular tools have been developed for $T$. equi to provide detection (ema-1 gene) and broad phylogenetic classification (18S rRNA gene) [20-22], to date there is no system available for genotyping with microsatellite markers. These highly variable markers provide fine-scale resolution for epidemiological tracking, evaluating genetic structure and identifying single versus mixed infections of haploid clones. Mixed infections are an important factor in protozoan diseases and can lead to increased virulence compared to single clone infections [23]. The use of both neutral microsatellite markers and gene sequences such as the
18S rRNA gene greatly enhances the ability to conduct population genetic analyses on pathogens [24].

The goal of this study was to understand genetic diversity among $T$. equi samples from North America. First, we examined full-length $18 \mathrm{~S}$ rRNA gene sequences to provide broad phylogenetic groupings for all samples into the four previously described clades of $T$. equi [21,25]. Next, we developed a panel of 18 microsatellite markers to provide finer-scale resolution of these genetic relationships. The first whole genome sequence of $T$. equi [26] provided the foundation for the development of highly variable microsatellite markers for $T$. equi. This genotyping panel was used to determine the genetic diversity of $T$. equi strains in the recent Texas outbreak and to trace back samples from potential sources of $T$. equi in the southern U.S. Both types of molecular data provided insight into the number of genetic lineages in the U.S. and the amount of genetic diversity within subpopulations.

\section{Methods}

\section{T. equi DNA samples and preparation}

The T. equi genomic DNA (gDNA) samples used in this study were collected by the USDA-ARS, Animal Disease Research Unit in Pullman, WA from routine screenings and as part of the response to recent outbreaks. We used a set of 38 samples from six states to maximize geographic diversity within the U.S. as much as possible (Table 1). Later, two samples were removed due to low data quality; Te0021 was excluded from $18 \mathrm{~S}$ analysis and Te0044 was excluded from the microsatellite analysis. A major focus was on samples from the Texas outbreak, which affected several hundred horses in 2009 [11]. Two isolates were derived from Amblyomma cajennense (Te0002) and Dermacentor variabilis (Te0035) ticks collected from multiple horses during the Texas outbreak [11]. These ticks were fed on uninfected horses at the USDA lab and once infections were confirmed the isolates were preserved as frozen blood stabilates, as previously described [11]. Another isolate, Te0042, was collected during the 2008 Florida outbreak [6]. Our positive control was a lab strain, Te0003, which originated from a Florida outbreak in the 1970s and was the same strain used for the first $T$. equi whole genome sequence (WGS) [26]. All but one of the samples were from infected U.S. horses; Te0044 was collected from a stray horse captured crossing the U.S.-Mexico border near Eagle Pass, TX. This horse tested as a weak seropositive for $T$. equi using the official cELISA regulatory test, but yielded negative results using nested PCR targeting ema-1. Infection was confirmed in this horse by passaging $100 \mathrm{~mL}$ of whole blood into a naïve splenectomized horse via intravenous inoculation. The transmission was successful and at the peak parasitemia 
Table $1 T$. equi samples extracted from horse blood for use in this study

\begin{tabular}{|c|c|c|c|c|c|c|c|}
\hline NAU ID & Location & County & $\begin{array}{l}\text { Year } \\
\text { collected }\end{array}$ & Details & $\begin{array}{l}\text { Passage details of } \\
\text { sample }\end{array}$ & MSAT & $\begin{array}{c}18 \mathrm{~S} \\
\text { group }^{* *}\end{array}$ \\
\hline Te0002* & TX & Kleberg & 2010 & $\begin{array}{l}\text { horse infected with Amblyomma } \\
\text { cajennense ticks collected from } 73 \text { TX } \\
\text { horses }\end{array}$ & $\begin{array}{l}\text { tick passage from field } \\
\text { (from multiple hosts) }\end{array}$ & yes & $A$ \\
\hline Te0003* & $\mathrm{FL}$ & & 2009 & $\begin{array}{l}\text { lab strain originally from 1970s outbreak } \\
\text { (whole genome sequence) }\end{array}$ & $\begin{array}{l}\text { multiple needle } \\
\text { passages }\end{array}$ & yes & A \\
\hline Te0004 & $\mathrm{TX}$ & Kleberg & 2009 & mare from index ranch breeding herd & $\begin{array}{l}\text { field blood } \\
\text { (direct from horse) }\end{array}$ & yes & A \\
\hline Te0005 & TX & Kleberg & 2009 & mare from index ranch breeding herd & $\begin{array}{l}\text { field blood } \\
\text { (direct from horse) }\end{array}$ & yes & A \\
\hline Te0006 & TX & Kleberg & 2009 & mare from index ranch breeding herd & $\begin{array}{l}\text { field blood } \\
\text { (direct from horse) }\end{array}$ & yes & A \\
\hline Te0007 & $\mathrm{TX}$ & Kleberg & 2009 & mare from index ranch breeding herd & $\begin{array}{l}\text { field blood } \\
\text { (direct from horse) }\end{array}$ & yes & A \\
\hline Te0008 & TX & Kleberg & 2009 & mare from index ranch breeding herd & $\begin{array}{l}\text { field blood } \\
\text { (direct from horse) }\end{array}$ & yes & A \\
\hline Te0009 & TX & Kleberg & 2009 & mare from index ranch breeding herd & $\begin{array}{l}\text { field blood } \\
\text { (direct from horse) }\end{array}$ & yes & A \\
\hline Te0010 & TX & Kleberg & 2009 & mare from index ranch breeding herd & $\begin{array}{l}\text { field blood } \\
\text { (direct from horse) }\end{array}$ & yes & A \\
\hline Te0011 & TX & Kleberg & 2009 & mare from index ranch breeding herd & $\begin{array}{l}\text { field blood } \\
\text { (direct from horse) }\end{array}$ & yes & A \\
\hline Te0012 & TX & Kleberg & 2009 & mare from index ranch breeding herd & $\begin{array}{l}\text { field blood } \\
\text { (direct from horse) }\end{array}$ & yes & A \\
\hline Te0013 & TX & Kleberg & 2009 & mare from index ranch breeding herd & $\begin{array}{l}\text { field blood } \\
\text { (direct from horse) }\end{array}$ & yes & A \\
\hline Te0014 & TX & Kleberg & 2009 & mare from index ranch breeding herd & $\begin{array}{l}\text { field blood } \\
\text { (direct from horse) }\end{array}$ & yes & A \\
\hline Te0015 & TX & Kleberg & 2009 & mare from index ranch breeding herd & $\begin{array}{l}\text { field blood } \\
\text { (direct from horse) }\end{array}$ & yes & A \\
\hline Te0016 & TX & Kleberg & 2009 & mare from index ranch breeding herd & $\begin{array}{l}\text { field blood } \\
\text { (direct from horse) }\end{array}$ & yes & A \\
\hline Te0017 & TX & Kleberg & 2009 & mare from index ranch breeding herd & $\begin{array}{l}\text { field blood } \\
\text { (direct from horse) }\end{array}$ & yes & A \\
\hline Te0018* & TX & & 2009 & $\begin{array}{l}\text { retired racehorse-epidemiologic trace out, } \\
\text { pastured with Be0019, Be0020 }\end{array}$ & $\begin{array}{l}\text { needle passage from } \\
\text { field }\end{array}$ & yes & A \\
\hline Te0019* & TX & Kleberg & 2009 & $\begin{array}{l}\text { pastured with Be0018-epidemiologic trace } \\
\text { out }\end{array}$ & $\begin{array}{l}\text { needle passage from } \\
\text { field }\end{array}$ & yes & A \\
\hline Te0020* & TX & Kleberg & 2009 & $\begin{array}{l}\text { pastured with Be0018-epidemiologic trace } \\
\text { out }\end{array}$ & $\begin{array}{l}\text { needle passage from } \\
\text { field }\end{array}$ & yes & A \\
\hline Te0021 & CA & & 2010 & $\begin{array}{l}\text { routine screening, presumed to be } \\
\text { unrelated to outbreak }\end{array}$ & $\begin{array}{l}\text { field blood } \\
\text { (direct from horse) }\end{array}$ & yes & $\begin{array}{l}\text { no } \\
\text { sequence } \\
\text { data }\end{array}$ \\
\hline Te0022 & CA & $\begin{array}{l}\text { San } \\
\text { Diego }\end{array}$ & 2010 & $\begin{array}{l}\text { routine screening, presumed to be } \\
\text { unrelated to outbreak }\end{array}$ & $\begin{array}{l}\text { field blood } \\
\text { (direct from horse) }\end{array}$ & yes & A \\
\hline Te0023 & GA & & 2010 & $\begin{array}{l}\text { routine screening, presumed to be } \\
\text { unrelated to outbreak }\end{array}$ & $\begin{array}{l}\text { field blood } \\
\text { (direct from horse) }\end{array}$ & yes & A \\
\hline Te0024 & GA & & 2010 & $\begin{array}{l}\text { routine screening, presumed to be } \\
\text { unrelated to outbreak }\end{array}$ & $\begin{array}{l}\text { field blood } \\
\text { (direct from horse) }\end{array}$ & yes & A \\
\hline Te0025 & GA & & 2010 & $\begin{array}{l}\text { routine screening, presumed to be } \\
\text { unrelated to outbreak }\end{array}$ & $\begin{array}{l}\text { field blood } \\
\text { (direct from horse) }\end{array}$ & yes & A \\
\hline Te0026 & GA & & 2010 & $\begin{array}{l}\text { routine screening, presumed to be } \\
\text { unrelated to outbreak }\end{array}$ & $\begin{array}{l}\text { field blood } \\
\text { (direct from horse) }\end{array}$ & yes & A \\
\hline
\end{tabular}


Table $1 \mathrm{~T}$. equi samples extracted from horse blood for use in this study (Continued)

\begin{tabular}{|c|c|c|c|c|c|c|c|}
\hline Te0027 & GA & & 2010 & $\begin{array}{l}\text { routine screening, presumed to be } \\
\text { unrelated to outbreak }\end{array}$ & $\begin{array}{l}\text { field blood } \\
\text { (direct from horse) }\end{array}$ & yes & A \\
\hline Te0028 & GA & & 2010 & $\begin{array}{l}\text { routine screening, presumed to be } \\
\text { unrelated to outbreak }\end{array}$ & $\begin{array}{l}\text { field blood } \\
\text { (direct from horse) }\end{array}$ & yes & A \\
\hline Te0029 & GA & & 2010 & $\begin{array}{l}\text { routine screening, presumed to be } \\
\text { unrelated to outbreak }\end{array}$ & $\begin{array}{l}\text { field blood } \\
\text { (direct from horse) }\end{array}$ & yes & A \\
\hline Te0033 & OK & & 2010 & $\begin{array}{l}\text { routine screening, presumed to be } \\
\text { unrelated to outbreak }\end{array}$ & $\begin{array}{l}\text { field blood } \\
\text { (direct from horse) }\end{array}$ & yes & A \\
\hline Te0034 & $\mathrm{CO}$ & & 2010 & $\begin{array}{l}\text { routine screening, presumed to be } \\
\text { unrelated to outbreak }\end{array}$ & $\begin{array}{l}\text { field blood } \\
\text { (direct from horse) }\end{array}$ & yes & A \\
\hline Te0035* & $\mathrm{TX}$ & & 2009 & $\begin{array}{l}\text { horse infected with Dermacentor variabilis } \\
\text { ticks collected from } 17 \text { TX horses }\end{array}$ & $\begin{array}{l}\text { tick passage from field } \\
\text { (from multiple hosts) }\end{array}$ & yes & A \\
\hline Te0039* & TX & Cameron & 2011 & index ranch-treatment study & $\begin{array}{l}\text { needle passage from } \\
\text { field }\end{array}$ & yes & A \\
\hline Te0040 & TX & Kleberg & 2011 & index ranch-housed at USDA & $\begin{array}{l}\text { field blood } \\
\text { (direct from horse) }\end{array}$ & yes & A \\
\hline Te0041 & TX & Kleberg & 2011 & index ranch-housed at USDA & $\begin{array}{l}\text { field blood } \\
\text { (direct from horse) }\end{array}$ & yes & A \\
\hline Te0042* & $\mathrm{FL}$ & & 2008 & 2008 Florida outbreak & $\begin{array}{l}\text { needle passage from } \\
\text { field }\end{array}$ & yes & A \\
\hline Te0045 & TX & Kleberg & 2011 & index ranch-treatment study & $\begin{array}{l}\text { field blood } \\
\text { (direct from horse) }\end{array}$ & yes & A \\
\hline Te0046 & TX & Kleberg & 2011 & index ranch-treatment study & $\begin{array}{l}\text { field blood } \\
\text { (direct from horse) }\end{array}$ & yes & A \\
\hline Te0044* & $\begin{array}{l}\text { U.S.MMX } \\
\text { border }\end{array}$ & Maverick & 2011 & $\begin{array}{l}\text { stray intercepted crossing TX-Mexico } \\
\text { border }\end{array}$ & $\begin{array}{l}\text { needle passage from } \\
\text { field }\end{array}$ & $\begin{array}{l}\text { no (amplification at } \\
\text { only } 7 / 18 \text { MSAT loci) }\end{array}$ & C \\
\hline
\end{tabular}

*Isolate, which refers to strain types derived from infections that were reproduced in the lab and available as frozen blood stabilates for future study.

${ }^{* *}$ As previously defined by Bhoora et al. [21], 2009 and illustrated in Figure 1.

(10\% parasitized erythrocytes) blood samples were collected for genotyping. Genomic DNA was isolated during acute infection and nested PCR targeting ema-1 again yielded negative results. Sequencing of the $18 \mathrm{~S}$ rDNA [GenBank:JQ390047] demonstrated 52 bp divergence from the $18 \mathrm{~S}$ gene found in the Florida $T$. equi whole genome sequence.

DNA from $T$. equi-infected horse blood was prepped with either the Qiagen ${ }^{\circledR}$ DNeasy Blood \& Tissue Kit or the Qiagen ${ }^{\circledR}$ Gentra PureGene Blood Kit (Valencia, CA). Before extraction, horse blood was centrifuged for 15 minutes at $2,000 \times \mathrm{g}$ to pellet red blood cells and the white blood cell layer was removed to minimize the amount of horse DNA in the final preparation. To obtain a higher yield of parasite DNA from some of the persistently infected horses that were sampled, anticoagulated whole blood was transferred to uninfected horses at the USDA lab. Blood was collected from the recipient for DNA extraction at peak parasitemia. The volume of blood transferred from persistently infected horses ranged between $10-60 \mathrm{~mL}$; the goal was to transfer a sufficient amount of blood to ensure that the full diversity of $T$. equi from the field horse was transferred to the naive uninfected horse. All animals used in these studies were handled according to protocols approved by the University of Idaho Institutional Animal Care and Use Committee (protocol \#2010-54).

All gDNA samples were processed with whole genome amplifications (WGAs) using Qiagen's REPLI-g ${ }^{\circledR}$ Mini Kit (Valencia, CA) to increase the limited amount of T. equi DNA present in some samples. The manufacturer's WGA protocol was followed, using $1 \mu \mathrm{L}$ of gDNA as template. The WGA procedure was also performed on samples with sufficient parasite DNA to insure that all samples were treated the same. In the case of single clone infections a WGA had no effect on the results, because genotypes were the same whether WGA or gDNA was used as template (data not shown). Conversely, the WGAs of mixed clone infections sometimes resulted in different clone ratios due to stochastic bias in the WGA process. To ensure adequate and unbiased representation of the entire genome, three independent WGA replicates were run for each T. equi sample. Each WGA replicate was validated using a PCR assay targeting the ema-1 gene [22]. The published assay was converted into a qPCR assay using $\mathrm{SYBR}^{\circledR}$ Green (Invitrogen, Grand Island, NY). WGAs were considered valid if they showed amplification with a cycle time of 30 cycles or less $\left(C_{t} \leq 30\right)$. Validated WGA replicates were pooled together to serve as templates for genotyping. 


\section{Sequence diversity of $18 \mathrm{~S}$ rRNA gene}

Primers specific to the $18 \mathrm{~S}$ rRNA gene of the genus Babesia were designed to amplify and sequence most of the $18 \mathrm{~S}$ region $(\sim 1,600 \mathrm{bp})$. Primers were designed using sequences obtained from GenBank for a variety of species including B. equi, B. gibsoni, B. major, B. occultans, $14 \mathrm{~B}$. bigemina and $6 \mathrm{~B}$. bovis (accession numbers listed in Additional file 1: Table S1). Sequences were aligned in MegAlign (DNASTAR Lasergene9, Madison, WI) and primer melting temperatures and interactions were investigated with Primer Express ${ }^{\circledR}$ Software v2.0 (Applied Biosystems, Carlsbad, CA). These primers were intended to be used with field samples, where non-target DNA can be present, so optimized primers were sent through a Primer-BLAST in GenBank against all prokaryotes and eukaryotes to ensure other eukaryotic organisms (e.g., protozoans, ticks, and equids) would not amplify. We designed two primers for amplification of the $18 \mathrm{~S}$ fragment to be sequenced: 18S_AllBab_1F (forward, 5' AGCCATGCATGTCTAAGTACAAGCTTTT-3') and 18S_AllBab_R3 (reverse, 5' - TCCGAATAATTCACCG GATCACTC-3'). The initial $10 \mu \mathrm{L}$ PCR contained final concentrations of the following reagents: $1 \mu \mathrm{L}$ of $10 \times$ buffer, $2.5 \mathrm{mM} \mathrm{MgCl}_{2}, 0.2 \mathrm{mM}$ dNTPs, $0.4 \mu \mathrm{M}$ of each primer, 0.8 units of Platinum ${ }^{\circledR}$ Taq (Invitrogen, Grand Island, NY) and $1 \mu \mathrm{L}$ of template (undiluted gDNA). The cycle conditions for the initial PCR consisted of $5 \mathrm{~min}$, $95^{\circ} \mathrm{C}$; $\left(30 \mathrm{sec}, 94^{\circ} \mathrm{C}\right.$; $\left.30 \mathrm{sec}, 60^{\circ} \mathrm{C} ; 75 \mathrm{sec}, 72^{\circ} \mathrm{C}\right) \times 40 \mathrm{cycles} ;$ $5 \mathrm{~min}, 72^{\circ} \mathrm{C}$; held at $16^{\circ} \mathrm{C}$. The $1,591 \mathrm{bp}$ PCR product $(2 \mu \mathrm{L})$ was visualized on a $1.5 \%$ agarose gel using $1 \mathrm{~kb}$ ladder (Invitrogen, Grand Island, NY) as a reference to confirm the correct target size and to estimate the dilution needed for cycle sequencing PCR. Water used for notemplate controls (NTC's) and DNA from uninfected horse blood as a negative control confirmed the assay amplified only $T$. equi. To remove excess primers and dNTPs after completion of the PCR, $1.5 \mu \mathrm{L}$ of ExoSAP-IT ${ }^{\circledR}$ (USB Corporation, Cleveland, OH) was added to each reaction and incubated for $15 \mathrm{~min}$ at $37^{\circ} \mathrm{C}$, followed by enzyme deactivation for $15 \mathrm{~min}$ at $80^{\circ} \mathrm{C}$. Dilutions of the PCR product were made depending on the band intensity from the gel electrophoresis. Bright bands were diluted 1:5 and faint bands were diluted 1:2.

The 18S rRNA gene amplicons of $37 \mathrm{~T}$. equi samples were sequenced with the Sanger method. Four internal primers were developed to allow double-coverage sequencing across the entire 1,591 bp amplicon. We used the diluted PCR product as template for BigDye ${ }^{\circledR}$ Terminator v3.1 cycle sequencing (Applied Biosystems, Carlsbad, CA). Every sample required six sequencing reactions with the following primers: AllBab_1F, sequence listed above; All_Babesia_F2, 5'-CAAGTCTGGTGCCAGCAGCC-3'; All_Babesia_F3, 5' -CAAAGTCTTTGGGTTCTGGGGG-
3'; All_Babesia_R1, 5' -CCCTACCGTCAAGCTGATGGG3'; All_Babesia_R2, 5'-ACGAATGCCCCCAACCGT-3'; AllBab_R3, sequence listed above. About half of our samples had poor reads for the outside forward (AllBab_1F) and reverse (AllBab_R3) contigs. In order to overcome this, nested forward and reverse primers (All_Babesia_ F1a, 5' - AGCTTTTATATGGTGAAACTGCGAAT-3'; All_Babesia_R3a, 5' - TCACTCGATCGGTAGGAGCGA$\left.3^{\prime}\right)$ were designed internally to the original PCR primers. The conditions for the cycle sequencing were $3 \mu \mathrm{L} 5 \times$ sequencing buffer, $1 \mu \mathrm{L}$ BigDye $^{\circledR}$ v3.1, $1 \mu \mathrm{M}$ of a single primer and $5 \mu \mathrm{L}$ of diluted PCR product producing a $10 \mu \mathrm{L}$ reaction. The cycle conditions for the cycle sequencing consisted of $5 \mathrm{sec}, 96^{\circ} \mathrm{C}$; $20 \mathrm{sec}, 50^{\circ} \mathrm{C} ; 4 \mathrm{~min}, 60^{\circ} \mathrm{C}$; (three first steps repeated 25 times) then held at $16^{\circ} \mathrm{C}$. An EDTA/ ethanol precipitation cleanup was performed on the products before they were sequenced on a 3130xl Sequencer (Applied Biosystems, Carlsbad, CA).

An assembly of sequences for each individual was accomplished in SeqMan (DNASTAR Lasergene9, Madison, WI) and all sequences were edited by visual inspection. The $37 \mathrm{~T}$. equi $18 \mathrm{~S}$ sequences were exported into BioEdit Sequence Alignment Editor (Carlsbad, CA) to align with 28 other Theileria 18S rRNA sequences from GenBank, including Theileria buffeli and T. annulata as outgroup taxa (accession numbers reported in Figure 1). T. buffeli and T. annulata are appropriate to serve as an outgroup to $T$. equi for the $18 \mathrm{~S}$ rRNA gene as demonstrated by Bhoora et al. [21]. The $6518 \mathrm{~S}$ rRNA gene sequences were aligned using Clustal W Multiple Alignment and gaps were visually inspected and adjusted. The sequences were imported into MEGA version 4 [27] where a maximum parsimony (MP) tree was constructed with a bootstrapping method applied. A consensus tree was created, with only bootstrap values $>50 \%$ reported (Figure 1 ).

\section{Identification of $T$. equi microsatellite sequences and primer design}

A whole genome sequence of the USDA Florida lab strain (Te0003) was used to discover microsatellite regions within the $T$. equi genome [26]. A variety of repeat sizes were searched, ranging from dinucleotide to hexanucleotide-repeats, using the software Tandem Repeats Finder [28] and MSATCOMMANDER [29]. Over a hundred loci were identified and primer pairs were designed at 75 of these with target sizes $<600 \mathrm{bp}$. Forward and reverse oligonucleotide primers were developed using NetPrimer (Premier Biosoft International, Palo Alto, CA) and SeqBuilder (DNASTAR Lasergene9, Madison, WI). First the optimal melting temperature $\left(\mathrm{T}_{\mathrm{m}}\right)$ of each locus was determined by a temperature gradient PCR using the same conditions as a single PCR (Additional file 2: Table S2) except that a $\mathrm{T}_{\mathrm{m}}$ range of 


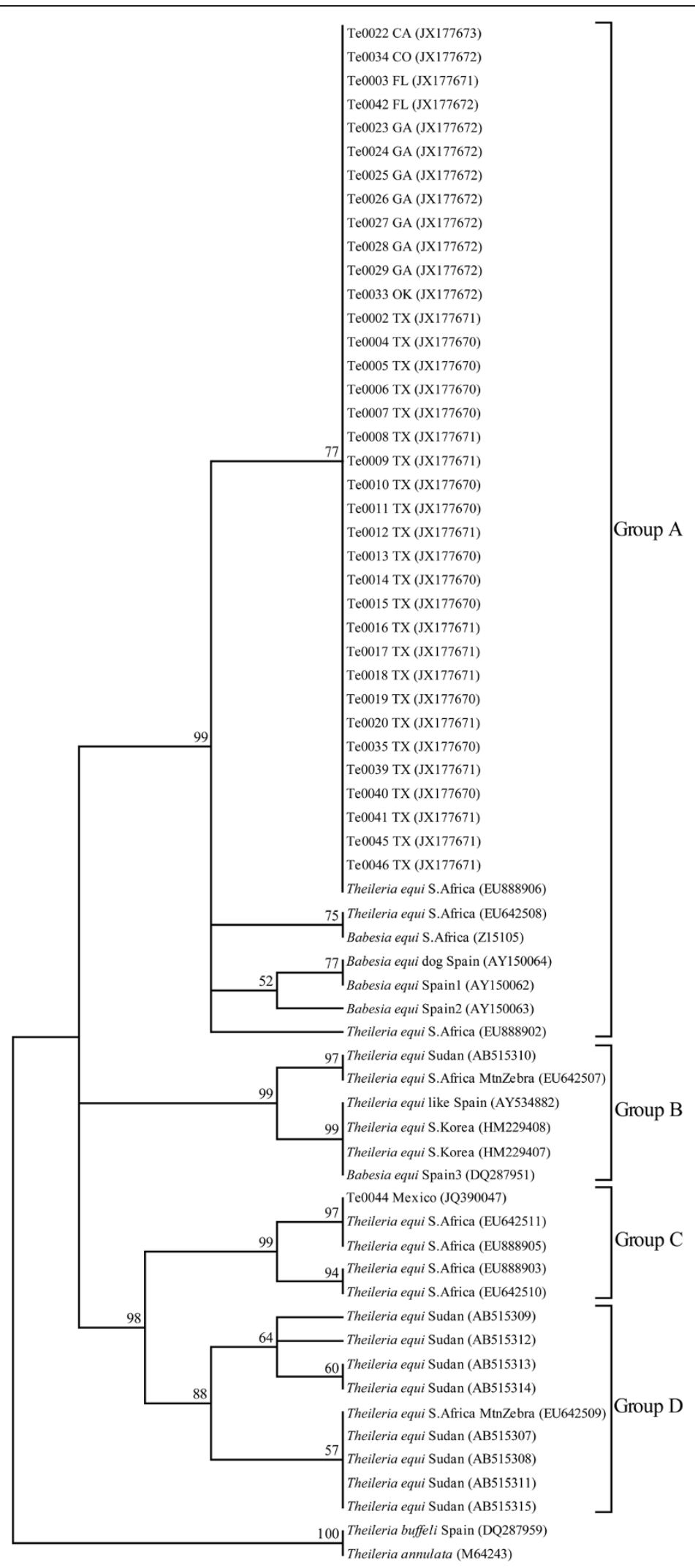

Figure 1 Maximum Parsimony tree of $T$. equi $18 \mathrm{~S}$ rRNA gene sequences with 1,000 bootstrap replicates. The tree is rooted with Theileria annulata and T. buffeli. 
$55-66^{\circ} \mathrm{C}$ was used. Then the loci were tested for polymorphism on nine Texas samples using single PCR conditions (Additional file 2: Table S2). If the locus proved to be polymorphic, then an external unlabeled primary forward primer was designed for use in a preamplification PCR. The pre-amplification PCR was followed by a heminested PCR using the original forward primer; this double-PCR process has been used to genotype a number of parasite species that often yield very low concentrations of DNA from host blood [20,30,31]. The external forward primer was first optimized using a temperature gradient. Then the PCR product from the primary PCR served as the template for the second (heminested) PCR, which used the internal forward primer. All validation PCRs were visualized on $2 \%$ agarose gels stained with SYBR ${ }^{\circledR}$ Safe (Invitrogen, Grand Island, NY) using a 100 bp DNA ladder to estimate sizes. After optimization, either 4 or 5 loci for each of the four chromosomes were found to yield robust PCR products yielding a total of 18 loci (Additional file 2: Table S2). The development of loci from all four chromosomes provided well-spaced markers across the whole genome. The internal forward primer from each locus was fluorescently labeled for high-resolution sizing on an AB3730 capillary machine (Applied Biosystems, Carlsbad, CA).

Electrophoresis was conducted on an AB3730 DNA Analyzer using GeneScan ${ }^{\mathrm{TM}} 1200$ LIZ $^{\circledR}$ Size Standard (Applied Biosystems, Carlsbad, CA). Each well contained $13.92 \mu \mathrm{L}$ of $\mathrm{Hi}-\mathrm{Di}^{\mathrm{TM}}$ Formamide (Applied Biosystems, Carlsbad, CA) with $0.08 \mu \mathrm{L}$ size standard and $1 \mu \mathrm{L}$ of diluted PCR product (1/100 for single PCR and 1/200 for heminested PCR). Plates were denatured for five minutes at $95^{\circ} \mathrm{C}$ and snap-cooled before each AB3730 run. Automatic scoring was accomplished with GeneMapper Software Version 4.0 (Applied Biosystems, Carlsbad, CA) and all calls were confirmed by visual inspection.

\section{Microsatellite marker amplification strategy}

Persistently infected horses carry only small levels of T. equi DNA, reflecting the low parasitemia of chronic infections $[22,30]$. These samples can yield variable PCR amplification and artifacts. Thus, it was critical to develop a reliable workflow that can be applied reproducibly to every sample to reduce genotyping errors and minimize sample to sample variation. We developed a robust 5 -step process to provide consistent and repeatable genotyping for $T$. equi:

1. To conserve the original DNA extraction, which often had low levels of target DNA, and increase the amount of starting target copies for PCR, we used WGAs from each sample as template for the initial round of PCRs.
2. After WGA, samples were initially genotyped using only internal primers in a multiplexed PCR (Additional file 2: Table S2 for compatible multiplexes).

3. If multiple alleles were detected at a single marker, the sample was screened again using unamplified gDNA as template and running each locus singly instead of in multiplex reactions. Genomic DNA provides a better representation of the actual allele abundance than WGAs and allowed us to determine the predominant allele (i.e. the one peak with the largest number of relative fluorescence units ( $\mathrm{rfu})$ ). Multiple alleles were scored if the rfu of minor peaks were $\geq 25 \%$ of the predominant peak [30].

4. When amplification was weak (<200 rfu), the samples were screened using WGA template in a single PCR without multiplexing.

5. If the above workflow still did not detect any alleles at a locus, we then used a single, heminested PCR. We first used WGA as template and if the sample still did not amplify gDNA template was used. This heminested PCR approach has been successfully employed in malaria genotyping for samples with low levels of target DNA [30,32]. We first amplified using the external, unlabeled primers for each locus individually, as described above (Additional file 2: Table S2). Then $1 \mu \mathrm{L}$ of this primary PCR was used as the template for a heminested PCR, again amplifying each locus separately.

Regardless of whether single or heminested PCR was used, all alleles were confirmed with a second, independent PCR. If two conflicting genotypes were found then a third PCR was conducted and the allele scored twice as being predominant was used for the final data. If three distinct predominant alleles were called then the most common allele of the three PCRs was used as a final datum. Our strategy was designed to be conservative in calling alleles that are truly present (as recommended by Anderson and others [30]); however, we realize this increases the risk of not capturing the full allelic diversity that may be present in some mixed infections. Frequencies for most common alleles were related to a sample's subpopulation (Texas, Georgia, Florida, etc.). Missing data at a locus was called when four or more attempts were made at amplification. Four horse samples were excluded from analysis because we were unable to amplify multiple loci, which indicated T. equi DNA was either too dilute in the sample or the chromosomal targets were simply absent in that particular strain. All PCR runs included water as an NTC and uninfected horse DNA to ensure false positives were not called due to primer interaction or amplification of horse DNA. 


\section{Population analysis}

We used population genetic analysis to determine linkage disequilibrium and genetic structure among the populations investigated in this study. As in many studies of apicomplexans, only primary alleles were used for data analysis [16,33-35]. The complete multi-clone genotype was only used to examine the percentage of samples exhibiting mixed clone infections versus single clone infections. To distinguish between a single clone infection with mutation events and a true mixed infection, we defined mixed clone infections as samples that displayed three or more loci with secondary alleles. Small populations ( $\mathrm{n} \leq 2$ samples) were included in tree construction, but excluded from all other marker validation and statistical analyses of population structure. Using the Texas population, we used the primary alleles amplified for each $T$. equi sample to test for linkage disequilibrium between all pairs of loci using 3060 permutations in FSTAT v2.9.3.2 (Goudet, J., 2001; http://www.unil.ch/izea/softwares/fstat.html). Data were imported into FSTAT using the Excel plug-in Microsatellite Excel Toolkit [36]. Population structure was estimated with Weir and Cockerham's $F_{\mathrm{ST}}$ estimator $(\theta)$ calculated in FSTAT. Using the Excel plug-in GenAlexv.6 [37] we calculated the expected heterozygosity $\left(H_{\mathrm{E}}\right)$ at the population level. A neighbor-joining (NJ) tree was generated from mean character distances using PAUP ver. 4.0b10 [38]. Confidence for the NJ tree was estimated by bootstrapping with 500 repetitions.

\section{Results}

\section{Phylogenetics of the $T$. equi 18S rRNA gene}

All T. equi samples from the U.S. grouped together into a single monophyletic clade based on $18 \mathrm{~S}$ rRNA gene sequences. The maximum parsimony (MP) tree was created using 116 parsimony informative sites. One of the 387 MP trees based on 18S rRNA gene sequences is shown in Figure 1 (tree length: 248 steps, consistency index: 0.7450, retention index: 0.9393). Separate phylogenetic analyses using MP and neighbor joining produced similar tree topologies with high nodal bootstrap values (Figure 1) and were consistent with two previous $T$. equi studies that used neighbor joining, maximum likelihood and Bayesian inference on the $18 \mathrm{~S}$ rRNA gene $[21,25]$. In the current analysis we recovered the four major phylogenetic groups (A, B, C and D) using GenBank sequences previously described $(n=28)[21,25]$ and the new U.S. sequences we describe in this study all $(n=36)$ fell into group A with sequences from South Africa and Spain (Figure 1). Nucleotide variation within group A is encompassed by less than ten single nucleotide polymorphisms (SNPs). Only two of these SNPs were observed in the U.S. sequences resulting in four distinct haplotypes
[GenBank:JX177670, JX177671, JX177672, JX177673], which suggests that a small source population is responsible for all recent U.S. outbreaks. All U.S. samples grouped together in a monophyletic clade with one other South African isolate [GenBank: EU888906]. One U.S. sample from California, Te0022 [GenBank: JX177673], shared an identical sequence with this African isolate.

The sample from the U.S.-Mexico border, Te0044 [GenBank:JQ390047], was different from the other U.S. samples by 48 SNPs and was robustly placed in group C identified by Bhoora et al. [21]. This isolate is clearly different from the other North American samples. As noted above, the horse from which this isolate originated was weakly seropositive for $T$. equi using the official cELISA regulatory test, but yielded negative results using nested PCR targeting ema-1 [22]. This isolate was nearly identical to two South African T. equi in GenBank [EU642511, EU888905], with only one SNP separating the Mexican sample from these two sequences.

\section{Genetic diversity}

In contrast to the $18 \mathrm{~S}$ gene sequences, microsatellite repeat markers exhibited a greater amount of genetic diversity among the U.S. T. equi samples. Two to eight alleles were found at each microsatellite locus (Additional file 2: Table S2). No linkage disequilibrium was detected in any combination of locus pairs. The expected heterozygosity $\left(H_{\mathrm{E}}\right)$ for the Texas population $(n=24)$ was 0.496 with a standard error of 0.044 . Identical dominant genotypes were observed for most of the samples from Georgia $(n=6)$, with only one sample differing at a predominant allele and four others differing at one or two secondary alleles. Despite its physical distance from Georgia, the sample from Oklahoma also shared a dominant haplotype with the Georgian samples, although it carried two unique secondary alleles. The two California samples shared alleles at only five markers. The isolate from the U.S.-Mexico border (Te0044) did not amplify well with this marker set. Only 7 of 18 loci amplified reliably, suggesting that only $T$. equi samples from $18 \mathrm{~S}$ group $\mathrm{C}$ may be typed successfully with this subset of markers (Additional file 2: Table S2). Unfortunately, we did not have samples available from groups B and D to test with this DNA fingerprinting system.

The set of 18 microsatellite markers revealed geographic structure among U.S. outbreaks of $T$. equi. Texas samples were loosely grouped into a large, diverse lineage (Figure 2). The genetic diversity in Texas may be due to a larger effective population size than other outbreaks and tick-borne transmission resulting in genetic recombination of $T$. equi. In contrast, Georgian samples separated into a separate subpopulation distinct from 


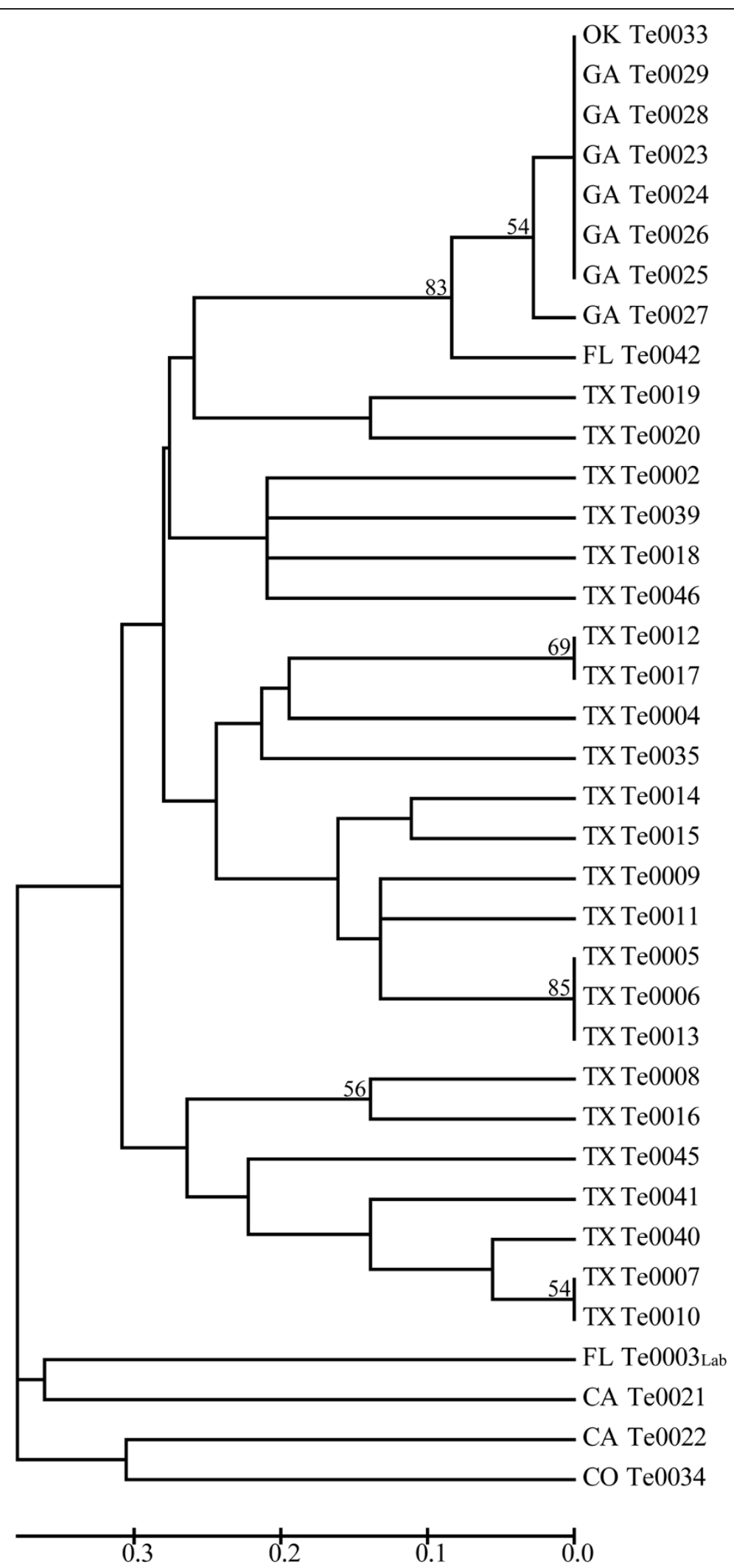

Figure 2 Mid-point rooted neighbor-joining tree constructed with T. equi microsatellite data with 500 bootstrap replicates (only values $>\mathbf{5 0} \%$ reported). Lab $=$ Lab strain, used for WGS. 
the Texas group. The Georgia clade consists mainly of a group of samples $(n=7)$ that share the same dominant haplotype. In addition to Georgia, this clade also includes a sample from Oklahoma, suggesting a similar source of infection. The samples from Colorado, California and the Florida lab strain did not cluster strongly with any other outbreaks on the NJ tree. The $F_{\mathrm{ST}}$ analysis is generally congruent with the NJ tree, since Texas and Georgia populations demonstrate strong differentiation $(\theta=0.414,99 \%$ CI: Lower $=0.290$, Upper $=0.504)$. Population sizes from all other states were too small for a robust $F_{\mathrm{ST}}$ analysis.

\section{Mixed and single infections}

Microsatellite analysis revealed that less than one-third of our total sample set $(n=10 ; 27 \%)$ contained mixed infections (2-3 clones). We made this estimate based on the greatest number of alleles at any single locus. However, this may be an underestimate if additional alleles were present but not detected. Of the 27 single infection samples, 15 (56\%) had unique multilocus haplotypes. Some of the samples with single infections bore evidence of microsatellite mutations, because we occasionally observed additional secondary alleles at 1-2 loci. Two groups of single infection samples that shared haplotypes (Te0012, Te0017 and Te0005, Te0006, Te0013) were collected from mares kept in a common pasture.

\section{Discussion}

Samples of $T$. equi from the recent outbreaks in Texas and Florida, as well as the other U.S. samples, were all assigned to the $18 \mathrm{~S}$ group A of Bhoora et al. [21]. All U.S. samples exhibit very little diversity within this clade, suggesting a limited introduction of a small number of clones into the U.S. This is in strong contrast to the large amount of $18 \mathrm{~S}$ diversity previously observed in South Africa. The sample from California (Te0022) that shares complete $18 \mathrm{~S}$ identity with a South African isolate [GenBank:EU888906] may suggest a shared source of introduction for California and the rest of the U.S. Conversely, the $T$. equi strain from the U.S.-Mexico border, Te0044, has a different $18 \mathrm{~S}$ lineage (group C) compared to the other U.S. samples. This isolate was undetectable with the ema-1 PCR and, because it has a $T$. equi genotype that is different from other samples, may require the use of a different detection assay to mitigate the risk of moving similar strains of T. equi into regions that are free of the parasite [39]. Te0044 is also distinctive because less than half of the microsatellite markers genotyped successfully. Additional development of microsatellite loci may be needed for genotyping all four of the major lineages of T. equi.
Our new microsatellite typing system allowed us to examine population structure of $T$. equi with greater resolution than provided by the $18 \mathrm{~S}$ gene. Although 36 U.S. samples had nearly identical $18 \mathrm{~S}$ sequences, at least 15 unique clones were detected using microsatellite markers. This finding suggests that since the initial introduction of a limited source into the U.S., T. equi populations have developed strong population structure across the spatial scale that we studied. Robust differentiation was observed between Texas and Georgia and this high $F_{\mathrm{ST}}$ value reflects the pattern also observed in the NJ tree. The greatest amount of genetic diversity was observed among the Texas samples, which might be expected from an outbreak with a greater effective population size [11]. The Texas outbreak was an especially valuable sample set for validating this panel of markers. Epidemiological data associated with each horse helps explain how variation is distributed in the Texas samples and validates identity between certain samples. For instance, the horses that yielded isolates with identical haplotypes, represented in the three clades observed in Figure 2, were mares that shared the same pasture. Therefore, it is highly likely that these horses were infected from a common source or passed the infection from one to another. It appears that transmission during the Texas outbreak was the result of tick-borne transmission; both Amblyomma cajennense and Dermacentor variabilis, as well as other tick species, may have been involved in transmission of $T$. equi to 292 of the 360 horses on the ranch at the center of the outbreak [11]. Some of the genetic diversity observed among the Texas outbreak samples could be due to recombination during sexual stage development in the tick gut, or by infection from multiple ticks that carried different $T$. equi clones. Additionally, the Texas samples might have been the result of a founding population of clones that carried a large amount of microsatellite variation.

The other U.S. samples differed in their level of genetic variation, which allows us to make inferences about the relatedness of these samples. The two California T. equi appeared to be quite distinct from samples from the other states and may have had origins unrelated to that of the Texas outbreak. Unfortunately, we do not have an adequate sampling of the California subpopulation $(n=2)$ to address this question. The 2010 samples from California and Colorado do not appear to be closely related to the samples collected farther east. The similar genotypes found in Georgia, Florida and Oklahoma suggest that there was a shared source of $T$. equi for these populations. Another possibility could be that dominant genotypes in Oklahoma and Georgia represent a highly virulent clone that outcompetes less virulent clones, thus giving 
the misleading appearance of a shared source of infection.

Our microsatellite typing system will also be valuable for typing isolates obtained from outbreaks resulting from iatrogenic transmission. The largest outbreak of equine piroplasmosis in the U.S. prior to Texas in 2009 was the Florida outbreak of 2008 in which 20 infected horses were identified and euthanized [6]. The epidemiological investigation of the Florida outbreak suggested that iatrogenic transmission was the primary cause. Unfortunately, we had only one isolate from this outbreak (Te0042), but if a larger collection of samples had been available this hypothesis could have been tested using strain typing. Very limited strain diversity would have been expected if transmission were purely mechanical.

A set of three samples illustrates the utility of this genotyping system to address specific epidemiological questions for certain individuals. T. equi strains Te0018, $\mathrm{Te} 0019$ and $\mathrm{Te} 0020$ were collected from horses pastured together. The horse infected with Te0018 was retired after a 20-year racing career, whereas Te0019 and Te0020 were epidemiologically linked to the Texas outbreak ranch. Had one of these horses been the source of infection for the others? The genotyping data suggest not, since Te0018 is distinctly different from Te0019 and Te0020 (Figure 2). Thus, it is highly likely that the sources of infection were unrelated. This trio of samples demonstrates the usefulness of microsatellite markers for tracing back individual samples, which is an important complement to the analysis of population structure for larger outbreaks.

\section{Conclusions}

The introduction of this tick-borne hemoparasite into susceptible regions has the potential to be very disruptive to the U.S. horse industry and should remain a major concern to the horse community and regulatory agencies. The ability of highly variable molecular markers to detect small genetic changes among samples provides a powerful tool for studying the epidemiology of parasitic diseases such as T. equi. Selectively neutral microsatellites have been successfully used to determine population structure of other apicomplexan pathogens such as the agent causing malaria, P. falciparum [16], bovine theileriosis, T. annulata [40], and bovine babesiosis, B. bovis [35]. Using our newly designed microsatellite panel we have identified multiple unique clones in recent U.S. outbreaks that were not apparent from 18S rRNA sequences, which are less sensitive to population level variations. Furthermore, we found strong genetic structure between two recent outbreaks, indicating that not all T. equi outbreaks can be traced to any single ranch. Although $18 \mathrm{~S}$ rRNA pinpointed a limited source of introduction, additional resolution using microsatellites indicated that very few samples were in fact identical. This marker system will be useful to help understand the epidemiology of any additional domestic and international T. equi outbreaks.

\section{Additional files}

Additional file 1: Table S1. GenBank entries used for primer design for sequencing the $18 \mathrm{~S}$ rRNA gene of Babesia spp.

Additional file 2: Table S2. Eighteen microsatellite $T$. equi loci with primer sequences and amplification conditions.

\section{Competing interests}

The authors declare that they have no competing interests.

\section{Authors' contributions}

$\mathrm{CH}$ performed the sequence alignments, participated in the molecular genetic studies, statistical analysis and drafted the manuscript. JB conceived the study, contributed with statistical analysis and drafting the manuscript. GS conceived the study, provided DNA samples and critically revised the manuscript. KP helped with primer design and laboratory experiments. MU provided DNA and scientific guidance. LK provided a whole genome sequence pivotal to this study. DW conceived the study and provided substantial scientific guidance. All authors read and approved the final manuscript.

\section{Authors' information}

Nucleotide sequence data reported in this paper are available in the GenBank $^{\text {TM }}$ database under the accession numbers JX177670, JX177671, JX177672, JX177673.

\section{Acknowledgements}

Sara Davis (USDA) provided outstanding technical assistance. Nancy Kumpula-McWhirter (WSU) provided archived blood samples. Ralph Horn and James Allison (USDA) assisted with animal work. Work at the USDA, ARS, Animal Disease Research Unit was funded by CRIS Project\# 5348-32000-03400D. This work was also supported by the Cowden Endowment at Northern Arizona University.

\section{Author details}

${ }^{1}$ Center for Microbial Genetics and Genomics, Northern Arizona University, 1298 S Knoles Drive, Flagstaff, AZ 86011, USA. ${ }^{2}$ USDA-ARS, Animal Disease Research Unit, 3003 Animal Disease Biotechnology Facility, Washington State University, Pullman, WA 99164, USA.

Received: 14 November 2012 Accepted: 5 February 2013 Published: 11 February 2013

\section{References}

1. Knowles DP, Kappmeyer LS, Stiller D, Hennager SG, Perryman LE: Antibody to a recombinant merozoite protein epitope identifies horses infected with Babesia equi. J Clin Microbiol 1992, 30(12):3122-3126.

2. Ueti MW, Palmer GH, Kappmeyer LS, Statdfield M, Scoles GA, Knowles DP: Ability of the vector tick Boophilus microplus to acquire and transmit Babesia equi following feeding on chronically infected horses with lowlevel parasitemia. J Clin Microbiol 2005, 43(8):3755-3759.

3. Uilenberg G: Babesia-a historical overview. Vet Parasitol 2006, 138(1-2):3-10.

4. Stiller D, Goff WL, Johnson LW, Knowles DP: Dermacentor variabilis and Boophilus microplus (Acari: Ixodidae): experimental vectors of babesia equi to equids. J Med Entomol 2002, 39(4):667-670.

5. Gerstenberg C, Allen WR, Phipps LP: Mechanical transmission of Babesia equi infection in a British herd of horses. In Proceedings of the eight international conference of equine infectious diseases. Dubai: Newmarket, R \& W Publications; 1999:217-222

6. Short MA, Clark CK, Harvey JW, Wenzlow N, Hawkins IK, Allred DR, Knowles DP, Corn JL, Grause JF, Hennager SG, Kitchen DL, Traub-Dargatz JL: 
Outbreak of equine piroplasmosis in Florida. J Am Vet Med Assoc 2012, 240(5):588-595.

7. Kuttler KL, Gipson CA, Goff WL, Johnson LW: Experimental Babesia equi infection in mature horses. Am J Vet Res 1986, 47(8):1668-1670.

8. Heim A, Passos LM, Ribeiro MF, Costa-Junior LM, Bastos CV, Cabral DD, Hirzmann J, Pfister K: Detection and molecular characterization of Babesia caballi and Theileria equi isolates from endemic areas of Brazil. Parasitol Res 2007, 102(1):63-68.

9. Ueti MW, Palmer GH, Scoles GA, Kappmeyer LS, Knowles DP: Persistently infected horses are reservoirs for intrastadial tick-borne transmission of the apicomplexan parasite Babesia equi. Infect Immun 2008, 76(8):3525-3529.

10. Rothschild CM, Knowles DP: Equine piroplasmosis. In Equine infectious diseases. Edited by Sellon DC, Long MT. St. Louis: Saunders, Elsevier; 2007:465-473

11. Scoles GA, Hutcheson HJ, Schlater JL, Hennager SG, Pelzel AM, Knowles DP Equine piroplasmosis associated with Amblyomma cajennense ticks, Texas, USA. Emerg Infect Dis 2011, 17(10):1903-1905.

12. USDA: Equine piroplasmosis domestic pathways assessment 2011: pathways assessment for the spread of the causative agents of equine piroplasmosis from the movement of a horse from a quarantined premises within the contiguous United States. USDA:APHIS:VS:CEAH: National Center for Risk Analysis Fort Collins, CO; 2011:62.

13. American Horse Council Foundation: The Economic Impact of the Horse Industry on the United States. Washington, DC: American Horse Council; 2005.

14. USAHA: One hundred and fourteenth annual meeting of the United States Animal Health Association: 11-17 November 2011. Minneapolis: Richardson Printing; 2011:412-413

15. Bashiruddin JB, Camma C, Rebelo E: Molecular detection of Babesia equi and Babesia caballi in horse blood by PCR amplification of part of the 16S rRNA gene. Vet Parasitol 1999, 84(1-2):75-83.

16. Anderson TJ, Haubold B, Williams JT, Estrada-Franco JG, Richardson L, Mollinedo R, Bockarie M, Mokili J, Mharakurwa S, French N, Whitworth J Velez ID, Brockman AH, Nosten F, Ferreira MU, Day KP: Microsatellite markers reveal a spectrum of population structures in the malaria parasite Plasmodium falciparum. Mol Biol Evol 2000, 17(10):1467-1482.

17. Colman RE, Vogler AJ, Lowell JL, Gage KL, Morway C, Reynolds PJ, Ettestad $P$, Keim P, Kosoy MY, Wagner DM: Fine-scale identification of the most likely source of a human plague infection. Emerg Infect Dis 2009, 15(10):1623-1625

18. Havryliuk T, Ferreira MU: A closer look at multiple-clone Plasmodium vivax infections: detection methods, prevalence and consequences. Mem Inst Oswaldo Cruz 2009, 104(1):67-73.

19. Keim P, Price LB, Klevytska AM, Smith KL, Schupp JM, Okinaka R, Jackson PJ Hugh-Jones ME: Multiple-locus variable-number tandem repeat analysis reveals genetic relationships within Bacillus anthracis. J Bacteriol 2000, 182(10):2928-2936

20. Battsetseg B, Lucero S, Xuan XN, Claveria FG, Inoue N, Alhassan A, Kanno T, Igarashi I, Nagasawa H, Mikami T, Fujisaki K: Detection of natural infection of Boophilus microplus with Babesia equi and Babesia caballi in Brazilian horses using nested polymerase chain reaction. Vet Parasitol 2002, 107(4):351-357.

21. Bhoora R, Franssen L, Oosthuizen MC, Guthrie AJ, Zweygarth E, Penzhorn $\mathrm{BL}$, Jongejan F, Collins NE: Sequence heterogeneity in the 18S rRNA gene within Theileria equi and Babesia caballi from horses in South Africa. Vet Parasitol 2009, 159(2):112-120.

22. Ueti MW, Palmer GH, Kappmeyer LS, Scoles GA, Knowles DP: Expression of equi merozoite antigen 2 during development of Babesia equi in the midgut and salivary gland of the vector tick Boophilus microplus. J Clin Microbiol 2003, 41(12):5803-5809.

23. Bell A, De Roode JC, Sim D, Read AF: Within-host competition in genetically diverse malaria infections: parasite virulence and competitive success. Evolution 2006, 60(7):1358-1371.

24. Keim P, Van Ert MN, Pearson T, Vogler AJ, Huynh LY, Wagner DM: Anthrax molecular epidemiology and forensics: using the appropriate marker for different evolutionary scales. Infect Genet Evol 2004, 4(3):205-213.

25. Salim B, Bakheit MA, Kamau J, Nakamura I, Sugimoto C: Nucleotide sequence heterogeneity in the small subunit ribosomal RNA gene within Theileria equi from horses in Sudan. Parasitol Res 2010, 106(2):493-498.
26. Kappmeyer LS, Thiagarajan M, Herndon DR, Caler E, Djikeng A, Gillespie JJ, Lau AOT, Roalson EH, Silva JC, Suarez CE, Ueti MW, Nene VM, Knowles DP, Brayton KA: The comparative genomic analysis and phylogenetic position of Theileria equi. BMC Genomics 2012, 13(603).

27. Tamura K, Dudley J, Nei M, Kumar S: MEGA4: molecular evolutionary genetics analysis (MEGA) software version 4.0. Mol Biol Evol 2007, 24(8):1596-1599.

28. Benson G: Tandem repeats finder: a program to analyze DNA sequences. Nucleic Acids Res 1999, 27(2):573-580.

29. Faircloth BC: MSATCOMMANDER: detection of microsatellite repeat arrays and automated, locus-specific primer design. Mol Ecol Resour 2008, 8(1):92-94

30. Anderson TJ, Su XZ, Bockarie M, Lagog M, Day KP: Twelve microsatellite markers for characterization of Plasmodium falciparum from finger-prick blood samples. Parasitology 1999, 119(Pt 2):113-125.

31. Waldenström J, Bensch S, Hasselquist D, Ostman O: A new nested polymerase chain reaction method very efficient in detecting Plasmodium and Haemoproteus infections from avian blood. J Parasitol 2004, 90(1):191-194.

32. Singh B, Bobogare A, Cox-Singh J, Snounou G, Abdullah MS, Rahman HA: A genus- and species-specific nested polymerase chain reaction malaria detection assay for epidemiologic studies. AmJTrop Med Hyg 1999, 60(4):687-692

33. Oura CAL, Asiimwe BB, Weir W, Lubega GW, Tait A: Population genetic analysis and sub-structuring of Theileria parva in Uganda. Mol Biochem Parasit 2005, 140(2):229-239.

34. Perez-Llaneza A, Caballero M, Baravalle E, Mesplet M, Mosqueda J, Suarez CE, Echaide I, Katzer F, Pacheco GM, Florin-Christensen M, Schnittger L: Development of a tandem repeat-based multilocus typing system distinguishing Babesia bovis geographic isolates. Vet Parasitol 2010, 167 (2-4):196-204

35. Simuunza M, Bilgic H, Karagenc T, Syakalima M, Shiels B, Tait A, Weir W: Population genetic analysis and sub-structuring in Babesia bovis. Mol Biochem Parasit 2011, 177(2):106-115.

36. Park SDE: Trypanotolerance in west African cattle and the population genetic effects of selection. University of Dublin, Ireland: PhD thesis; 2001.

37. Peakall R, Smouse PE: GENALEX 6: genetic analysis in excel. Population genetic software for teaching and research. Mol Ecol Notes 2006, 6(1):288-295.

38. Swofford DL: PAUP*. Phylogenetic Analysis Using Parsimony (*and other methods). version 4. Sunderland, MA, USA: Sinauer Associates; 1998

39. Bhoora R, Quan M, Matjila PT, Zweygarth E, Guthrie AJ, Collins NE: Sequence heterogeneity in the equi merozoite antigen gene (ema-1) of Theileria equi and development of an ema-1-specific TaqMan MGB assay for the detection of T. Equi. Vet Parasitol 2010, 172(1-2):33-45.

40. Weir W, Karagenc T, Gharbi M, Simuunza M, Aypak S, Aysul N, Darghouth MA, Shiels B, Tait A: Population diversity and multiplicity of infection in Theileria annulata. Int J Parasitol 2011, 41(2):193-203.

doi:10.1186/1756-3305-6-35

Cite this article as: Hall et al:: Genetic characterization of Theileria equi infecting horses in North America: evidence for a limited source of U.S. introductions. Parasites \& Vectors 2013 6:35.

\section{Submit your next manuscript to BioMed Central and take full advantage of:}

- Convenient online submission

- Thorough peer review

- No space constraints or color figure charges

- Immediate publication on acceptance

- Inclusion in PubMed, CAS, Scopus and Google Scholar

- Research which is freely available for redistribution 